\title{
The Role of Modified Chitosan in Bone Engineering in Diabetes Mellitus: Analytical Review
}

\author{
Bolshakov IN*, Levenets AA, Patlataya NN, Nikolaenko MM, Dmitrienko AE, Ryaboshapko EI, Matveeva ND, Ibragimov IG, \\ Kotikov AR and Furtsev TV
}

Krasnoyarsk State Medical University named after Prof. V.F.Voino-Yasenetsky, Russia

*Corresponding author: Bolshakov IN, Krasnoyarsk State Medical University named after Prof. V.F.Voino-Yasenetsky, Russia, E-mail: bol.bol@mail.ru

Received: 15 Feb, 2021 | Accepted: 15 Mar, 2021 | Published: 22 Mar, 2021

Citation: Bolshakov IN, Levenets AA, Patlataya NN, Nikolaenko MM, Dmitrienko AE, et al. (2021) The Role of Modified Chitosan in Bone Engineering in Diabetes Mellitus: Analytical Review. Int J Dent Oral Health 7(3): dx.doi.org/10.16966/2378-7090.356

Copyright: (C2021 Bolshakov IN, et al. This is an open-access article distributed under the terms of the Creative Commons Attribution License, which permits unrestricted use, distribution, and reproduction in any medium, provided the original author and source are credited.

\section{Summary}

The review is devoted to the state of the problem during the reconstruction of bone defects in the maxillofacial region, topical issues of the mechanisms of biopolymers action, mainly chitosan, during stimulation of angiogenesis and osteogenesis under conditions of the formation of bone cavities of critical size in the maxillofacial area, as well as under conditions of the development of an inflammatory process with Mellitus diabetes. In the analysis of research papers, the international information bases Web of Science, Scopus, PMC free article, PubMed, Google Scholar were used, mainly over the past 12 years. The main emphasis in the scientific review is placed on the points of application of the chitosan biopolymer in the implementation of already known signaling pathways for the regulation of osteogenesis. Studies have shown that chitosan, as an independent polymer, and especially chitosan copolymers, play an important role in the regulation of osteoblastogenesis and angiogenesis, reducing the osteoclastic response, preventing osteomalacia of the alveolar ridge, accelerating the formation of a new well-vascularized bone.

Keywords: Osteogenesis; Angiogenesis; Diabetes mellitus; Chitosan; Polysaccharide biopolymers; Nano-structured structures; Bone defects of critical size; Bone bioengineering; Growth factors; Scaffold; Regeneration

\section{Introduction}

The state of the problem in the reconstruction of bone defects in the maxillofacial region

Why usually large bone defects heal unsatisfactorily? Large bone defects, which constitute a critical size and exceed the reparative potential, regardless of their localization, are not eliminated even with long monitoring periods. The presence of calcium-phosphate compounds in the structure, modern osteoconductive materials widely used in dental practice, for example, Bio-Oss scaffolds, mature and immature mesenchymal stem cells, induced pluripotent stem cells, as well as individual osteogenic growth factors often do not lead to the complete elimination of the defect [1-8]. Even after 8 weeks of observation of artificial alveolar cavities of critical size of $5 \mathrm{~mm}$ in rats, the bone defect cut by $38.3 \%$ [5]. Predictable reconstruction of the normal structure and functionality of the tooth support module remains a challenge [9]. Extensive bone loss for various reasons is a serious problem in clinical practice. Despite the advances in the development of modern materials for bone grafting, autobone transplantation is still considered the "gold standard." Autotransplantation combines the natural properties necessary for bone grafting: the osteoconductivity-the presence of a niche with osteogenic cells and conditions for their growth into the maternal tissue with the formation of new bone, as well as osteoinduction-stimulation of proliferation in the niches of stem cells and their differentiation into osteogenic cells necessary for bone regeneration [10-14].

However, it is important to point out that the artificial chemical compounds making up the functional construct are more stable and have a longer active half-life compared to protein cytokines and growth factors. It has been proven that such compounds better promote osteogenic differentiation of stem cells in vitro [15]. In the work [16] female Sprague-Dawley rats underwent critical $7 \mathrm{~mm}$ skull defects in the midline of the parietal bone using trephine under copious saline. The bone defect was filled for 8 weeks with biodegradable alginate or collagen matrix with an immobilized chimeric anti-BMP- $2 \mathrm{mAb}$. Micro-CT analysis (Micro-CAT II, Siemens Medical Solutions Molecular Imaging, Knoxville, TN) with a $10 \mu \mathrm{m}$ scan at $60 \mathrm{kV}$ and $110 \mu \mathrm{A}$ at a spatial resolution of $18.7 \mu \mathrm{m}$ estimated local bone mineral density (BMD) $(\mathrm{mg} / \mathrm{cm}-3)$ in the defect area with the calculation of the bone volume fraction (BV/TV). Histo-morphometric analysis of sections of samples stained with hematoxylin and eosin (using a digital camera Olympus DP50, Japan) confirmed the findings of micro-CT analysis-the formation of significant areas of newly formed bone with a high content of osteocytes, high bone density compared to controls. In the area of the defect, connective tissue with unorganized collagen 
fibrils is formed. A point load on the regenerative tissue followed by a local fracture directly in the area of the newly formed tissue indicates a low bone maturity in the control. Thus, in the absence of an automaterial, only the introduction of a functional bone into a defect using cell combinations, including progenitor cells, of highly biocompatible substrates, capable of self-organization and high biocompatibility of the formulated molecular architecture, of growth factors can close an extensive bone defect. This goal is a promising strategy for producing hybrid materials that can demonstrate suitable biomimetic and mechanical properties [17-19].

Why are materials for bone grafting not effective enough in the area of the bone defect? The use of plastic materials for the elimination of bone defects is the filling of bone cavities with substances on an organic and inorganic basis, as well as the use of a combination of molecular structures. For example, the use of pure phase $\beta$-tricalcium phosphate (bioactive ceramics) ( $\beta$-TCP), as well as coated with poly (lactide-co-glycolide) (PLGA), as a basis for bone regeneration when the rat's bilateral bone cavity of the tibia is closed. Size showed in the pure (negative) control a fairly low degree of new bone formation within 6 weeks of observation. A study of the experimental group of animals revealed the beginning of the formation of new bone and signs of remodeling of the old bone, the ingrowth of cells from the surrounding tissue into biomaterials. However, both the pure $\beta$-TCP phase and the PLGA/ $\beta$-TCP combination did not fill the entire volume of the bone cavity for 6 weeks, despite the presence of proliferating cells outside and inside the plastic materials [20]. The use of various types of bone grafts or bone substitutes for periodontitis, demineralization of the tooth root surface, growth factors and differentiation of cells, proteins of the enamel matrix has shown that the best results are achieved only when combining technologies aimed at implementing the already known mechanisms of angiogenesis and osteogenesis. However, there is still no direct evidence confirming the combined approach in clinical use, primarily morphometric analysis [21]. The use of only alloplastic matrices of different molecular structures in bone grafting has demonstrated limited or no periodontal regeneration [22]. Despite the positive observations in animal models and successful treatment results in patients in the clinic, illustrations of morphometric analysis, today there are no protocols for the complete restoration of periodontal disease in progressive periodontitis for reasons of subjective assessment of the effectiveness of therapy, both from clinical conclusions and information received from the patient $[23,24]$.

\section{The role of angiogenesis in bone formation and regeneration}

The processes of intramembranous ossification associated with direct differentiation of mesenchymal stem cells into osteoblasts are characteristic of the formation of flat bones in the maxillofacial region. These processes are based on high vascularization of connective tissue, which allows maintaining bone regeneration and remodeling in an active state $[25,26]$. Active osteogenesis cannot be achieved without creating preconditions for high vascularization of the artificial graft [27]. The main reason for failure when attempting to close a critical size defect is the lack of ability to achieve regeneration of highly vascularized bone in vivo [28]. Seeding a biodegradable matrix with a combination of mesenchymal stem cells (MSC) and peripheral blood endothelial progenitor cells (PB-EPC) in a 1:1 ratio demonstrates excellent osteogenic and vasculogenic differentiation of these cells. After sowing this cell mass onto the matrix and translation into its pore system, the explants are filled with a microvascular network and mineral mass. The vascularization process is accompanied by continuous secretion of vascular endothelial growth factor (VEGF), which is essential for the normal proliferation of endothelial cells of newly formed vessels and osteoblast precursors. This is an important condition for the formation of jawbones [29,30]. It is known that osteoblasts express VEGF and its receptors (VEGFR-1, VEGFR-2) [31]. This expression plays an important role not only in the differentiation of osteoblasts but also in their viability [32]. An earlier chain of events in the regulation of bone formation is the induction of VEGF expression by osteoblasts such factors as BMP, FGF, TGF- $\beta$, IGF, and Vitamin D3 [33]. Therefore, VEGF is involved in the regulation of not only the formation of the bone vasculature but also in the differentiation of osteoblasts, which confirms the molecular cross-links between the bone-associated endothelium and osteoblasts. However, there is still doubt that VEGF directly regulates bone mineralization. However, conditional VEGF knockout in the osteoblast lineage affects osteoblast differentiation despite negative results using recombinant VEGF or anti-VEGF antibodies [34,35]. Therefore, VEGF secretion links osteogenesis and angiogenesis, stimulating the translation of proliferating endothelial cells into the osteogenesis zone. This leads to direct control of the differentiation and function of osteoblasts and osteoclasts, achieving bone remodeling. Knockout of VEGF isoforms in animals disrupts the morphogenesis of bone growth zones [36,37]. On the other hand, overexpression of, for example, the isoform of VEGF164 in murine adult osteoblasts results in a change in bone morphology with an osteosclerosis pattern. It was found that VEGF artificially increases bone mass through the 2-kinase pathway mediated by the VEGF receptor and phosphatidylinositol-3-kinase. This factor induced the transcriptional activity of beta-catenin in endothelial and osteoblastic cells, probably by modulating the phosphorylation of 3-beta-glycogenase synthase $[38,39]$. The process of vascularization of flat bone is the translation of small-diameter capillaries into a thin avascular layer of loose mesenchyme surrounding the center of mesenchymal condensation. In this niche, mesenchymal cells secrete VEGF, recruiting endothelial cells. Islets of ossification appear, into the zone of which micro-vessels are introduced. The communication of the internal and external vascular network is accompanied by mineralization with thickening of the bone from the inside out with the compaction of osteoblasts near the capillaries [40]. A cone consisting of osteoclasts is introduced into the reconstruction area of the new cortical bone, which lyses the old bone matrix. It is assumed that a blood vessel moves after the cone, providing the building material and growth factors for the mass of osteoblast precursors that occupy the posterior position. An equally important role in this reciprocal process is played by mature osteocytes, which regulate the rate of ossification of the damaged zone through the $\mathrm{Wnt} / \beta$-catenin signaling pathway, the main regulatory pathway of osteoblast function. This molecular and morphological picture confirms the close relationship between angiogenesis and osteogenesis $[41,42]$. Therefore, unlike most other tissues, bone tissue is capable of true regeneration, i.e., to healing without the formation of fibrous scar tissue [43]. It's worth pointing out that the endothelium of the arterioles of the bone is a unique object in relation to interaction with a number of growth factors that differentiate bone progenitor cells $[44,45]$. The uniqueness of the endothelium of arterioles lies in the expression of a high level of hypoxia-inducible transcription factor 1 alpha (HIF1- $\alpha$ ), which stimulates neoplasm of blood vessels at the border of cartilage and bone. In addition, endothelial cells intensively express adhesion molecules of platelet endothelial cells (CD31), forming the CD31/ endomucin system (CD31 (hi) -Emcn (hi), the number of these cells decreases with age [46]. It is important to indicate that these cells are capable of interacting with bone progenitor cells [44]. When this population of endothelial cells matures, the Notch signaling pathway is activated, which triggers the proliferation of these cells, which leads 
to the activation of osteogenesis [45]. Activation of the intercellular transmembrane signaling protein Notch in the vascular endothelium stimulates the secretion of the factor-the signaling protein Noggin in osteoprogenitor cells, which triggers the process of their differentiation and maturation into osteoblasts [40]. Proliferating osteoblasts respond by stimulating microvessel formation by expressing VEGF-A. Thus, the level of osteogenesis proper supports the level of angiogenesis.

\section{Angiogenesis and diabetes mellitus}

The factors that determine the adverse outcomes of bone regeneration in diabetes mellitus are poorly understood. It has been established that diabetes mellitus inhibits bone regeneration as a result, first of all, of compromising the vascular microenvironment [47]. The authors of the publication convincingly showed that in the study of the regeneration of annular defects in the skull bone of different sizes in 16-week-old ZDF rats and their age control Zucker Lean (ZL) rats, different recovery quality was recorded. The authors quantitatively determined the parameters of the vasculature inside the defects by perfusing the animal's vasculature with microfila and scanning it after decalcification. Comparative results showed that large bone defects with a diameter of $8 \mathrm{~mm}$ showed impaired healing kinetics with a decrease in the volume of newly formed bone $(\mathrm{p}<0.01)$ and surface area $(\mathrm{p}<0.01) 8$ weeks after intervention. At the same time, bone formation in smaller defects did not depend on either the size of the diabetic state [48]. The main criterion for impaired bone regeneration in diabetes mellitus is a decrease in the volume and area of the newly formed vascular network. Established microangiopathy in mice [49] in induced diabetes mellitus in animals, causes vasoconstriction and impairment of blood flow in bones [50]. Hyperglycemia affects the macro-and microstructure of the bone, characterized by structural bone deficiency: thinner cortical layers and changes in cancellous bone, namely, thinner and wider trabeculae, occlusion of the vascular canals in the bone with mineralized tissue [51-53]. A similar morphological pattern is observed in diabetic mice induced by streptozotocin (STZ) [54]. The authors found a decrease in bone expression of the platelet adhesion molecule in endotheliocytes (CD31), as well as a drop in the levels of HIF-1 $\alpha$ and VEGF) compared to control animals. Thus, impaired bone angiogenesis in diabetes mellitus is the main trigger for bone formation imbalance. Artificial introduction of factors stimulating both angiogenesis and osteogenesis into the osteogenesis system leads to the effective elimination of bone deficiency, for example, in the model of avascular necrosis of the femoral head in rabbits. Simultaneous administration of adeno-associated viral vectors to animals carrying sequences encoding VEGF-A, which is involved in angiogenesis, and BMP-7, which is involved in osteogenesis, effectively improve the healing of the femoral head $[55,56]$.

\section{Osteogenesis disorders in the development of diabetes mellitus}

In hyperglycemia, low bone regeneration and periodontal loss is supported by activation of the Receptor of Advanced Glycation Endproducts (RAGE) and increased production of reactive oxygen species (ROS) with the formation of active cytokine expression and inflammatory response with an increase in tumor necrosis factor (TNF), IL-1 $\beta$, IL- 6 and IL-18 [57-59]. Superoxidation (O-2) process in the mitochondrial electron transport chain as a result of hyperglycemia [60-63] and membrane-bound NADPH oxidase activity generates high concentrations of hydrogen peroxide $\left(\mathrm{H}_{2} \mathrm{O}_{2}\right)$ in organelles. An overproduction of peroxides leads through the activation of the signaling pathway of blood plasma mRNA: the receptor-activator of nuclear factor ligand-kappa-B (RANKL) to the differentiation and proliferation of osteoclasts [64-66]. It has been established that AGEs induce osteoblast apoptosis, reduce their number and impair bone formation [67-69]. If the formation of reactive oxygen species is artificially suppressed with the help of specific absorbers, then the effect of damage from high concentrations of NADPH does not occur [70]. Likewise, if one excludes the isoforms of the transcription factor forkhead box-O (FoxO1,3,4) from the chain of molecular events using RANKL and thus deactivates catalase, this will lead to an increase in the concentration of $\mathrm{H}_{2} \mathrm{O}_{2}$ in osteoclasts, reduce the expression of antioxidant enzymes and accelerate osteoclast differentiation and survival. Such events will weaken the bar structure of mineralized bone [71,72]. Thus, the process of violation of ossification is oriented towards the proliferation of osteoclasts $[73,74]$, activation of proapoptotic genes and apoptosis of osteoblasts, which leads to erosion and weakening of the bone trabeculae [75-77], suppression of the expression of osteogenesis factors [78]. In works [79-83] it has been convincingly shown that in the development of periodontitis in the presence of diabetes mellitus, high levels of IL- $1 \beta$, TNF- $\alpha$, chemokine MCP-1 and prostaglandin E2 induce and prolong osteoclast-mediated bone resorption. Lipopolysaccharide (LPS) stimulated monocytes from type 1 diabetes mellitus patients to produce significantly more TNF-Alpha, IL-1-beta, and PGE2 compared to normoglycemic patients [83,84]. At the same time, LPS-stimulated phagocytes secreting IL-1-beta increased the collagenolytic activity of fibroblasts of the periodontal ligament of the gum [85]. This process may be accompanied by a 5 -fold increase in apoptosis of mucous cells, osteoblasts and a 2.7-fold increase in apoptosis of periodontal ligament fibroblasts, while the level of osteoclasts increases by 2-4 times [74]. At the same time, one of the final mechanisms of inducing differentiation of hematopoietic precursors into osteoclasts against the background of high levels of TNF, IL-1 $\beta$, IL- 6 in rats with streptozotocin-induced diabetes mellitus, and in humans, also IL-17, IL-23, C-RP [86], is the activation of the signaling pathway of blood plasma mRNA: receptoractivator of nuclear factor ligand-kappa-B (RANKL) and a decrease in osteoprotegerin (OPG). These reactions lead to an increase in the RANKL/OPG ratio [87-90]. This activation is accompanied by the destruction of the alveolar bone and an increase in the number of osteoclasts in the periapical and furcal areas [91]. Bone destruction against the background of high levels of proinflammatory cytokines, an increase in the levels of glycosylated proteins, for example, collagen in the inflammatory reaction zone in the bone, and high activity of osteoclasts are accompanied by a decrease in the differentiation, and activity of osteoblasts and an increase in apoptosis of these cells [92-94].

In humans, in contrast to animals with a model of periodontitis, the process proceeds more difficult and longer due to the presence of the atherogenic nature of inflammation [95]. If in animals or humans, hyperglycemia is poorly controlled, then the proliferation of osteoclasts increases and bone resorption increases $[96,97]$. A very important addition to the process of inflammation in osteolysis is the activation of bacterial infection in progressive periodontitis against the background of diabetes mellitus, which is one of the triggers of apoptosis. Reduced control over the level of hyperglycemia activates the microbial flora in the oral cavity and, thus, increases the nature of complications. Superficial and deep probing using biofilms of subgingival areas in patients with high and low levels of glycated hemoglobin (HbAlc) showed using quantitative polymerase chain reaction (PCR) that in tissue layers at a depth of more than $5 \mathrm{~mm}$ with a degree of $\mathrm{HbAlc}$ greater than $8 \%$, levels significantly increase contamination with Porphyromonas gingivalis, Tannerella forsythia, Treponema denticola, 
Eubacterium nodatum, Parvimona micra, Fusobacterium nucleatum ssp. and Pravotella intermedia [98].

The exclusion of the action of caspase- 3 from the molecular chain of events with the help of a specific inhibitor, which normally stimulates the proliferation of osteoblasts, increases the number of apoptotic cells adjacent to the bone by 10 times, and leads to the proliferation of osteoclasts, increases the level of TNF in cells by 2 times. If TNF is artificially inhibited, then against the background of type 2 diabetes mellitus, the expression of bone morphogenetic protein (BMP) and the main fibroblast growth factor (FGF), osteocalcin [76]. As a result, longterm oxidative stress in progenitor cells and osteocytes responsible for bone remodeling plays a negative role in the construction of highquality bone tissue $[72,99]$.

\section{The role of chitosan substrates and other polysaccharides in stimulating osteogenesis and angiogenesis}

Numerous works on the use of plastic materials to eliminate bone defects have confirmed that materials based on collagens, alginates and chitosan are the best examples of biomaterials obtained from natural resources $[18,100-103]$. The unique features of these polymers have attracted many researchers: high volume-to-surface ratio, high porosity on a surface with very small pore size, the ability to control biodegradation and mechanical properties commensurate with the rate of tissue regeneration under culture conditions, high biocompatibility, wide possibilities of chemical and physical modification with useful biological properties for use in tissue engineering and organ replacement in regenerative medicine, primarily due to their biochemical similarity with highly hydrated components of glycosaminoglycans (GAG) from connective tissue, very low toxicity [104-106].

Recently, synthetic biodegradable polymers have become very important in the field of biomaterials and tissue engineering because there is no need for additional surgeries to remove implants or scaffolds. Therefore, much attention is paid to the synthesis of biodegradable polymers. Moreover, researchers in animal experiments have begun to use a combination of natural and synthetic biodegradable constructs more often $[107,108]$. The authors used chemical, physical crosslinking or the principle of physical interaction of biopolymers, for example, to obtain soft three-dimensional structured hydrogels. These products were used for tissue bioengineering or as delivery systems for targeted products to the affected area from gelatin, hyaluronic acid and chondroitin sulfate, starch and cellulose, and their chemical derivatives $[109,110]$. When using a biodegradable three-dimensional scaffold, it must be designed to maintain structural integrity, function and degrade under control until new tissues are formed to support their function. Such properties of 3D scaffolds demonstrate the interaction of materials and cells, including cell adhesion, proliferation, growth, differentiation, as well as, which is very important, mechanical strength, developed porosity of the substrate, and the ability to translate the entire matrix-cell structure into the area of the bone defect.

Research in the field of bone tissue engineering using modern three-dimensional biodegradable matrices containing growth factors and a combination of cell mass has been significantly intensified in recent years. Low mechanical strength, instability of maintaining the shape of the matrix base in native tissues limited the use of chitosanbased polysaccharide matrices for bone bioengineering [102,111114], alginate [115-120], chondroitin sulphate [121], hyaluronic acid [122-124]. Improvement of the mechanical properties of these unique polymers has been achieved by the development of copolymers [125131], also polyelectrolyte composites based on physical synthesis [132135]. Preclinical trials of polysaccharide matrices have confirmed high biocompatibility, controlled biodegradation and high mechanical strength $[136,137]$. These properties were preserved when inorganic components are included in the matrix, for example, hydroxyapatites [138-140], carbon material [141], calcium phosphate compounds [142145], ions of various metals [146-148]. For example, it is well established that osteoblasts can proliferate at an excellent rate on chitosan-coated titanium surfaces compared to titanium alone [149]. This coating induces minimal inflammatory response [150]. Protonated forms of chitosan, for example, with the help of weak organic acids, improve the functional properties of the hydrogel. It is known that the presence of ascorbic acid in the chitosan molecule is necessary for the survival of human osteoblasts in vitro [151]. It has been convincingly proven that matrix surfaces grafted with hydroxyl $\left(\mathrm{OH}^{-}\right)$and amino groups $\left(\mathrm{NH}_{3}^{+}\right)$strongly regulate osteoblast-specific expression of genes for the proliferation of vascular endothelium, myoblasts, proliferation and differentiation of osteoblasts, regulation of enzymatic activity of alkaline phosphatase and matrix of mineralization [152,153]. In this case, the roughness of the surface of the matrix is also important: the nano-sized compared with the micro-sized surface is a stimulus for the proliferation of endothelial cells and osteogenic cells [154].

Incorporation of multifunctional growth factors into matrices, growth factors beta (TGF beta) such as BMP-2 [155-161] and BMP-7 [162-165] approved for clinical use, BMP-9 [166,167], VEGF for the development of perfused, large-volume tissue-engineered constructs $[168,169]$. A cocktail containing TGF- $\beta$ in the presence of a full reservoir of specific recombinant structural and signaling proteins in high concentrations (initiators, regulators, inhibitors, modulators) [170,171], HGF, IGF-1 [172], adhesion molecules (fibrin, fibronectin and vitronectin) [173-176] significantly increased the efficiency of bone bioengineering. When using nano-sized chitosan polysaccharide as a delivery system to mesenchymal stem cells of the BMP-2/BMP7 multicistronic plasmid using highly efficient cytomegalovirus (CMV) promoter sequence, it significantly enhances the functionality of the activated pBMP-2 gene and leads to accelerated regeneration of critical bone in an animal model compared to untreated controls $(\mathrm{p}<0.001)$ [177].

The design of composite polymer systems can demonstrate clear spatiotemporal kinetics of the release of growth factors, which is critical for the control of biological processes. The sequential launch of the first stage of angiogenesis with the release of VEGF, FGF and angiopoietin-2 (Ang-2) will lead to the stimulation of the proliferation and migration of new endothelial cells with the formation of immature micro-vessels. The subsequent stage of release of angiopoietin-1 and PDGF-BB into the extracellular medium will stabilize the newly formed blood vessels $[178,179]$. If we make a strategy for the simultaneous or sequential release of angiogenic growth factors from the matrix into the environment, then the effect of vascularization will be enhanced [180]. Such Spatio-temporal control is also observed when osteogenesis factors are introduced into biodegradable matrices [181]. Sequential delivery of BMP-2 and BMP-7 in encapsulated nanoparticles based on a copolymer of poly-lactic and poly-glycolic acids (PLG), pre-incorporated into three-dimensional fiber scaffolds based on chitosan $[182,183]$, and enhanced the differentiation of mesenchymal stem cells. Poly-electrolyte copolymer of poly-4-vinyl pyridine ( $\mathrm{P}(4) \mathrm{VN}$ ) and alginic acid in different concentrations and different characteristics of pores during foaming of matrices loaded with growth factors BMP-2 and BMP-7 released target products at different rates. The presence of two or more growth factors in the environment increased osteogenic differentiation [184-190]. Matrix delivery of angiogenic and osteogenic growth factors (VEGF-2 and BMP-2) or BMP-2 alone shows, in comparison with positive and 
negative controls (11-15\%), a significant filling with newly formed bone tissue in a critical skull size defect in rats $(8 \mathrm{~mm})$ after 12 weeks of follow-up (53-55\%). The morphological analysis confirmed good contact of the newly formed bone with the boundary of the maternal bone and the polymer framework itself [191]. It should be noted that the inclusion of only VEGF-2 into the matrix does not lead to enhanced bone formation. Only the participation of two factors simultaneously complements the effect of osteogenesis. The addition of three factors VEGF, PDGF-BB and TGF- $\beta 1$ to the alginate-sulfate matrix (like heparin-sulfate) with the design of their sequential and prolonged release from the matrix shows the excellent form of the vasculature compared, for example, with the effect of introducing only the main growth factor fibroblasts (bFGF) or with the absence of the sulfated form of alginate in the system [192-194]. However, it is well known that the family of extra-, transcellular and intracellular proteins of fibroblast growth factor (FGFs) and their receptor apparatus (FGFRs) play an important role in the regulation of the vital activity of osteoblast precursors [195].

How does the presence of chitosan or other polysaccharide scaffold base in the bone cavity affect the molecular markers responsible for angiogenesis and osteogenesis? These questions are still uninformative [196]. It is known that heparinized chitosan or collagen-chitosan matrices containing growth factors demonstrate a high level of angiogenesis in comparison with the control series of animals. Using the example of skin defects, healing occurs against the background of stable delivery of recombinant human granulocyte-macrophage colony-stimulating factor (rhGM-CSF) and high expression of VEGF and TGF-beta- 1 in the area of inflammation. The factors also create a favorable development in the skin wound of the population of dermal fibroblasts, which confirms the development of progressive angiogenesis [197,198]. It is known that chitosan enhances the adhesion and aggregation of platelets enriched with PDGF and transforming growth factor- $\beta$ (TGF- $\beta$ ), recruiting cells from the systemic circulation. The release of high concentrations of PDGF and TGF- $\beta$ into the medium leads to an increase in the mitogenic activity of bone cells.

If the task is set to incorporate nanoparticles of the heparinchitosan complex into the porous structure of polyethylene glycol hydrogel (PEGG) and implant the construct in tissues, the efficiency of the delivery of vector molecules into cells increases, the level of angiogenic factors, such as sonic hedgehog (Shh) and vascular endothelial factor, increases significantly, Growth (VEGF). Thus, the effect of over-expression of angiogenesis molecules is observed. This action enhances endothelial recruitment and blood vessel neoplasm [199]. It is important to point out that the degree of deacetylation of the chitosan matrix plays an important role both in the timing of degradation of the structure and in the degree of endothelialization [200]. No less important is the fact of stimulation of vascular neoplasm in the presence of only highly deacetylated chitosan polymer in tissues without preliminary inclusion of vascular formation and growth factors in its composition. It has been established that constructions based on liquid polysaccharides, for example, the sulfated form of chitosan, chitosan ascorbate, chitosan hydrochloride, the sodium salt of alginic acid, when introduced into the fascial sheaths of the neurovascular bundles [201-203] create the effect of therapeutic angiogenesis. The concept of the active inclusion of molecular markers of angiogenesis and further morphological restructuring of the qualitative and quantitative characteristics of the vessels consists in the artificial placement of chitosan and other biopolymers in the immediately affected area. Biopolymers can affect the intimate and middle layers of blood vessels when localized in para-adventitious layer. Such dislocation of polysaccharides leads to the normalization of not only the cellular and intercellular structure, but also the macroscopic characteristics of the vessel, such as the thickness of the intima, media, the diameter of the main arteries, and the number of newly formed microvessels. It is very important for future research that the adventitial and para-adventitia layers take the main place for therapeutic intervention and delivery of therapeutic ingredients to solve the issues of managing the process of not only angiogenesis but also osteogenesis [204]. In cases of bone regeneration, this concept of angiogenesis management may play an important role in the repair of giant defects in hard tissue.

Self-implantation of liquid forms of polymers into the paraventitial zone of the main arteries of the hind limbs in animals demonstrates a local restoration of the thickness of the middle layer by $29-38 \%$, reducing the ratio of the thickness of the media to the diameter of the vessel lumen by $37-44 \%$. This effect also takes place in the overlying segment of the main vessel. The dislocation of the sulfated form of chitosan in the paravasal space for 20 days provides a decrease in the ratio of subintimal myocytes in the middle segment of the artery by $27 \%$, enhancing the effect of reconstruction in the upper segment of the vessel by $68 \%$. At the site of polymer resorption in the adventitia zone, the effect of the formation of a microvascular bed is observed, the number of new vessels in rat's increases by $22-49 \%$, in rabbits by $56-66 \%$. It is important to emphasize the independent mechanism of therapeutic angiogenesis in the presence of highly deacetylated chitosan. The implantation of chitosan constructs in the tissue of an intact animal is accompanied by an $85-96 \%$ increase in the number of microvessels after 30 days of the post-implantation period [203]. Such a local angiogenic effect of chitosan hydrogels is confirmed by fundamental research when non-covalent and covalent copolymers containing chitosan and a sulfated ingredient, for example, heparin, are used in experiments. The angiogenic effect must develop due to the binding of pro-angiogenic growth factors on any copolymer containing chitosan [205-207]. The calculation is carried out on the nano-structuring of chitosan using a sulfated heparin molecule and the formation of a depot capable of binding and releasing angiogenic growth factors, leading, during its biodegradation, to the formation and growth of vascular tissue $[208,209]$. There is a suggestion that the $\mathrm{N}$-acetylglucosamine unit of chitosan can bind to the fibroblast growth factor and, thus, stimulate angiogenesis and proliferation of osteoblastlike cells [210]. At the same time, the release of alkaline phosphatase (ALP) into the medium indicates an increase in metabolism in bone tissue [211]. It should be clarified that the understanding of the mechanism of chitosan action substrate on the growth factors of osteogenesis can be determined only when the polymer is used, first of all, as an independent ingredient without the participation of exogenous factors in the system.

From the standpoint of the physicochemical characteristics of polysaccharide matrices, the porosity and pore size of the glycosaminoglycan (GAG) dynamic substrate, which is comfortable for osteoblasts and vascular endothelium, should be about 100-150 $\mu \mathrm{m}$. At the same time, if we are talking about the regeneration of hard tissue, for example, a new bone in the bone cavity, then the rate of degradation of the matrix base should be lower than for rapidly proliferating cells to provide an additional level of control over the cell, With biodegradation of the polymerits surface is constantly renewed and changes the pathways of cell mass migration. Cell mass also does not live in static conditions [153]. In addition, a dynamic matrix, taking into account the current trends in the inclusion of cells of different populations and functionality, should have the properties of their comfortable interaction [212]. 


\section{The use of polysaccharide polymers in the closure of extensive bone defects in diabetes mellitus}

Taking into account the well-known scientific findings that reveal the mechanisms of activation of osteogenesis and angiogenesis using biodegradable polysaccharide biopolymers as the main substrates both for independent regulation and for the overexpression of regulatory factors, it becomes necessary to use such structures to close the critical size of bone defects in diabetes mellitus. As mentioned above, the solution to such a problem is a difficult project, since the systemic impairment of bone formation in diabetes mellitus affects multiple extracellular, transcellular and intracellular mechanisms associated with osteoinduction and osteoconduction. On the one hand, in diabetes mellitus, a cytokine storm is formed with mRNA expression IL- $1 \beta$, IL6 , IL-8, IL-10, TNF- $\alpha$, MCP-1. This process is accompanied by high RANKL expression and decreased OPG expression, overexpression in osteoblasts of TLR- 2, -3, -4, -9 and the development of osmotic stress. At the same time, oxidative stress in cells with the accumulation of peroxides due to a decrease in the activity of the FOxO1,2,3 system and catalase. These are important conditions for osteoclast activation, bone resorption, osteomalacia, and prolonged inflammation in the periodontal area. On the other hand, polysaccharide biopolymers, for example, chitosan or alginate, are able, independently or in the presence of exogenous growth factors, to increase the quality and volume of mineralization (expression of RunX2, Col-1), the total number of osteocytes in newly formed bone (NOex-C), regulate the activity of the FGFs protein family (FGF2,9,18), bone growth factors (BMP2,6,7,9), IGFs family (IGF-I, IGF-II), PDGF, superfamilies TGFs. In the presence of chitosan, alginate in a complex with hydroxyapatite (nano-hydroxyapatite) in vitro and in vivo through the activation of the Wnt signaling pathway, the levels of $\beta$-catenin, cyclin D1 increase, the growth of angiogenesis factors (VEGF, CD31) in the precursors of osteoblasts and mature osteoblasts. The process is accompanied by an increase in the amount of collagen in the area of the newly formed bone with a high activity of serum bone alkaline phosphatase (BAP). The result of molecular transformations is the active differentiation of mesenchymal stem cells and osteoblast precursors, the formation of a large mass of osteocytes filling a bone defect of critical size, microvascular endotheliocytes in the Haversian canals. The preclinical use of chitosan constructs for the regeneration of the alveolar and jawbones showed positive promising results in accelerating the osseointegration of dental implants and the restoration of critical-sized defects. The inclusion of insulin-like growth factor binding protein-3 (IGFBP-3) into chitosan nanoparticles, and conjugation with the IGFBP-3 DNA plasmid, followed by implantation of the construct in the rat mandibles leads to enhanced synthesis and increased expression of morphogenetic bone proteins (BMP-2, BMP -7) in comparison with the control, inhibits the activator of the nuclear factor ligand kappa- $\mathrm{B}$ receptor (RANKL), increases the synthesis of osteopontin (OPN). A similar effect develops upon implantation of the BMP2 DNA plasmid [213]. The end result of such molecular transformations is a decrease in the induction of osteoclastogenesis molecules and an increase in the volume of the newly formed bone surrounding chitosan implants. In the control series of animals, induced diabetes mellitus forms structural changes consisting in a decrease in bone mass and an increase in signs of an inflammatory response, a decrease in the expression of anti-inflammatory molecules of the peroxy proliferator activation of the gamma receptor (PPAR $\gamma$ ), and the formation of a bone molecule in comparison with intact rats. Developing osteoporosis reduces the stability and longevity of implants [214,215]. The mechanism of osseointegration in the presence of a chitosan polysaccharide is realized through activation of mitochondrial biogenesis and the
Wnt/ $\beta$-catenin signaling pathway. Thus, in rats with induced diabetes mellitus, delivery of the PPAR $\gamma$ gene by local dental implants increases cell viability stimulates osseointegration, new bone formation, and mineralization. It was found that chitosan nanoparticles $10-20 \mathrm{~nm}$ in size, carrying PPAR $\gamma$ in their composition, are able, on the one hand, to suppress the expression of tumor necrosis factor-alpha (TNF- $\alpha$ ), interleukin-1 beta (IL-1 $\beta$ ), inducible nitric oxide synthase (iNOS), cyclooxygenase-2 (COX-2) and matrix metalloproteinase-2 (MMP-2), alkaline phosphatase (ALP), on the other hand, induce the expression of transcription factor-2 (RUNX-2), reduce the expression of the receptor activator ligand NF- $\mathrm{KB}$ (RANKL) and increase the expression of the bone morphogenetic protein (BMP-7) [216]. Researchers recommend the PPAR $\gamma$ chitosan delivery system as a therapeutic gene for dental implantation in diabetic patients.

\section{Conclusion}

Thus, the suppression of the activity of the cytokine storm and the secretion of reactive oxygen species (ROS) in the cells of osteogenesis means the removal of the inflammatory response of the tissue. These studies once again confirm the broad functional nature of modified chitosan implants when creating comfortable conditions for angiogenesis and osteogenesis in order to eliminate bone defects in the maxillofacial region of a critical size. The biological activity of chitosan is significantly enhanced by the inclusion of other biodegradable natural polymers, bioceramics, and growth factors of vascular and bone tissue $[217,218]$. The universal nature of polysaccharide polymers increases its promising use, since dynamic mechanical analysis, for example, of chitosan structures, which fill the bone cavities, shows elastic behavior under dynamic compression, the frameworks have mechanical stability in a wet state, exhibit an accumulation modulus of $4.21 \pm 1,04 \mathrm{MPa}$ at a frequency of $1 \mathrm{~Hz}[106,219]$.

Research in our laboratory on the production and use of a nanostructured construct: chitosan-alginate-hydroxyapatite (CS-SAHA) for closing bone defects of critical size in the mandible of Wistar rats showed the process of the early formation of a newly formed vascular network and bone tissue in the defect zone without additional use of exogenous growth factors. This construction can be a promising material for the fast and complete elimination of large bone defects in conditions of sub-compensated or uncompensated diabetes mellitus and periodontitis.

Clinical observations show that bone tissue defects, after removal of odontogenic cysts within the range of up to diameter $2-2.5 \mathrm{~cm}$, heal independently through the organization of a blood clot. Studies [220] showed that when filling a bone defect using modified chitosan, early activation of the angiogenic reaction occurs and the subsequent rapid resorption of damaged bone beams. This is the trigger for the formation of new bone. The results of these studies confirmed that the presence of modified chitosan in the bone cavity ensures the delimitation of the newly formed bone from the surrounding soft tissues with the formation of a coarse connective tissue membrane. This process does not require additional creation of a boundary film during an intervention. The authors of the present study did not use exogenous growth factors in the chitosan transfer system, since the initial stage of research was aimed at determining the limitations and conditions for the reconstruction of a large bone cavity using only a polymer. At the same time, the healing of large bone wounds remains a problem in the clinic. A comprehensive program for studying the processes of osteogenesis in large bone defects using various osteoplastic materials, in particular products of highly purified chitosan, will determine the possibilities and conditions for eliminating large bone cavities. Thus, further research should be directed to the combination of several 
biocompatible substrates, including the chitosan polymer, in the presence of combinations of activated osteoblasts and progenitor cells, bone and vascular growth factors. Such a combination in the bioconstruct will be designed for the self-organization of the new bone, the closure of bone defects of critical size in diabetes mellitus.

\section{References}

1. Kigami R, Sato S, Tsuchiya N, Sato N, Suzuki D, et al. (2014) Effect of basic fibroblast growth factor on angiogenesis and bone regeneration in non-critical-size bone defects in rat calvaria. J Oral Sci 56: 17-22.

2. Schmitz JP, Hollinger JO (1986) The critical size defect as an experimental model for craniomandibulofacial nonunions. Clin Orthop Relat Res 205: 299-308.

3. Lou X (2015) Induced Pluripotent Stem Cells as a new Strategy for Osteogenesis and Bone Regeneration. Stem Cell Rev Rep 11: 645651

4. Korn P, Schulz MC, Range U, Lauer G, Pradel W (2014) Efficacy of tissue engineered bone grafts containing mesenchymal stromal cells for cleft alveolar osteoplasty in a rat model. J Craniomaxillofac Surg 42: 1277-1285.

5. Raposo-Amaral CE, Bueno DF, Almeida AB, Jorgetti V, Costa CC, et al. (2014) Is bone transplantation the gold standard for repair of alveolar bone defects? J Tissue Eng.

6. Borzunov DY, Shastov AL (2019) Mechanical solutions to salvage failed distraction osteogenesis in large bone defect management. Int Orthop 43: 1051-1059.

7. Shanbhag S, Pandis N, Mustafa K, Nyengaard JR, Stavropoulos A (2017) Alveolar bone tissue engineering in critical-size defects of experimental animal models: a systematic review and metaanalysis. J Tissue Eng Regen Med 11: 2935-2949.

8. Smith JO, Tayton ER, Khan F, Aarvold A, Cook RB, et al. (2017) Large animal in vivo evaluation of a binary blend polymer scaffold for skeletal tissue-engineering strategies; translational issues. J Tissue Eng Regen Med 11: 1065-1076.

9. Chen F-M, Jin $Y$ (2010) Periodontal tissue engineering and regeneration: current approaches and expanding opportunities. Tissue Eng Part B Rev 16: 219-255.

10. Behnia H, Khojasteh A, Esmaeelinejad M, Naghdi N (2012) Growth factor carriers in bone formation: a systematic review. J Islamic Dental Assoc Iran 24: 150-167.

11. Hassani A, Khojasteh A, Alikhasi M (2008) Anterior palate of the maxilla as a donor site for oral and Maxillofacial reconstructive procedures. Asian J Oral Maxillofac Sur 20: 135-138.

12. Dimitriou R, Jones E, McGonagle D, Giannoudis PV (2011) Bone regeneration: current concepts and future directions. BMC Med 9: 66.

13. De Long WG Jr, Einhorn TA, Koval K, McKee M, Smith W, et al. (2007) Bone grafts and bone graft substitutes in orthopaedic trauma surgery. A critical analysis. J Bone Joint Surg Am 89: 649-658.

14. Schieker M, Heiss C, Mutschler W (2008) Knochen ersatz materialien. Unfallchirurg 111: 613-620.

15. Zhang Z (2011) Bone regeneration by stem cell and tissue engineering in oral and maxillofacial region. Front Med 5: 401-413.

16. Ansari S, Phark J-H, Duarte S Jr, Paulino da Silva M, Sharifzadeh N, et al. (2016) Biomechanical analysis of engineered bone with antiBMP2 antibody immobilized on different scaffolds. J Biomed Mater Res B Appl Biomater 104: 1465-1473.
17. Tabatabaei FS, Motamedian SR, Gholipour F, Khosraviani K, Khojasteh A (2012) Craniomaxillofacial bone engineering by scaffolds loaded with stem cells: A systematic review. J Dent Sch 30: 115-131.

18. Khan F, Tanaka M, Ahmad SR (2015) Fabrication of polymeric biomaterials: a strategy for tissue engineering and medical devices. J Mater Chem B 3: 8224-8249.

19. Henkel J, Woodruff MA, Epari DR, Steck R, Glatt V, et al. (2013) Bone Regeneration Based on Tissue Engineering Conceptions-A $21^{\text {st }}$ Century Perspective. Bone Res 3: 216-248.

20. Bizenjima T, Takeuchi T, Seshima F, Saito A (2016) Effect of poly (lactide-co-glycolide) (PLGA)-coated beta-tricalcium phosphate on the healing of rat calvarial bone defects: a comparative study with pure-phase beta-tricalcium phosphate. Clin Oral Implants Res 27: 1360-1367.

21. Miron RJ, Guillemette V, Zhang Y, Chandad F, Sculean A (2014) Enamel matrix derivative in combination with bone grafts: A review of the literature. Quintessence Int 45: 475-487.

22. Ivanovic A, Nikou G, Miron RJ, Nikolidakis D, Sculean A (2014) Which biomaterials may promote periodontal regeneration in intrabony periodontal defects? A systematic review of preclinical studies. Quintessence Int 45: 385-395.

23. Kao RT, Nares S, Reynolds MA (2015) Periodontal regenerationintrabony defects: a systematic review from the AAP regeneration workshop. J Periodontol 86: S77-S104.

24. Sculean A, Nikolidakis D, Nikou G, Ivanovic A, Chapple ILC (2000) Biomaterials for promoting periodontal regeneration in human intrabony defects: a systematic review. Periodontol 68: 182-216.

25. Franz-Odendaal TA (2011) Induction and patterning of intramembranous bone. Front Biosci (Landmark Ed) 16: 2734-2746.

26. Berendsen AD, Olsen BR (2015) Bone development. Bone 80: 14-18.

27. Udagawa A, Sato S, Hasuike A, Kishida M, Arai Y, et al. (2013) MicroCT observation of angiogenesis in bone regeneration. Clin Oral Implants Res 24: 787-792.

28. Amini AR, Xu TO, Chidambaram RM, Nukavarapu SP (2016) Oxygen Tension-Controlled Matrices with Osteogenic and Vasculogenic Cells for Vascularized Bone Regeneration in vivo. Tiss Eng Part A 22: 610-620.

29. Wiszniak S, Mackenzie FE, Anderson P, Kabbara S, Ruhrberg C, et al. (2015) Neural crest cell-derived VEGF promotes embryonic jaw extension. Proc Natl Acad Sci U S A 112: 6086-6091.

30. Liu Y, Olsen BR (2014) Distinct VEGF functions during bone development and homeostasis. Arch Immunol Ther Exp (Warsz) 62: 363-368.

31. Deckers MM, Karperien M, van der Bent C, Yamashita T, Papapoulos SE (2000) Expression of vascular endothelial growth factors and their receptors during osteoblast differentiation. Endocrinology 141: 1667-1674.

32. Alonso V, de Gortázar AR, Ardura JA, Andrade-Zapata I, AlvarezArroyo MV, et al. (2008) Parathyroid hormone-related protein (107-139) increases human osteoblastic cell survival by activation of vascular endothelial growth factor receptor-2. J Cell Physiol 217: 717-727.

33. Zelzer E, Olsen BR (2005) Multiple roles of vascular endothelial growth factor (VEGF) in skeletal development, growth, and repair. Curr Top Dev Biol 65: 169-187.

34. Liu Y, Berendsen AD, Jia S, Lotinun S, Baron R, et al. (2012) Intracellular VEGF regulates the balance between osteoblast and adipocyte differentiation. J Clin Invest 122: 3101-3113. 
35. Berendsen AD, Olsen BR (2015) Regulation of adipogenesis and osteogenesis in mesenchymal stem cells by vascular endothelial growth factor A. J Intern Med 277: 674-680.

36. Hu K, Olsen BR (2016) Osteoblast-derived VEGF regulates osteoblast differentiation and bone formation during bone repair. J Clin Invest 126: 509-526.

37. Maes C, Carmeliet P, Moermans K, Stockmans I, Smets N, et al. (2002) Impaired angiogenesis and endochondral bone formation in mice lacking the vascular endothelial growth factor isoforms VEGF164 and VEGF188. Mech Dev 111: 61-73.

38. Maes C, Goossens S, Bartunkova S, Drogat B, Coenegrachts L, et al. (2010) Increased skeletal VEGF enhances beta-catenin activity and results in excessively ossified bones. EMBO J 29: 424-441.

39. Shoham AB, Rot C, Stern T, Krief S, Akiva A, et al. (2016) Deposition of collagen type I onto skeletal endothelium reveals a new role for blood vessels in regulating bone morphology. Development 143: 3933-3943.

40. Filipowska J, Tomaszewski KA, Niedźwiedzki $t$, Walocha JA, Niedźwiedzki T (2017) The role of vasculature in bone development, regeneration and proper systemic functioning. Angiogenesis 20: 291-302.

41. Niedźwiedzki T, Filipowska J (2015) Bone remodeling in the context of cellular and systemic regulation: the role of osteocytes and the nervous system. J Mol Endocrinol 55: R23-R36.

42. Maes C, Kobayashi T, Selig MK, Torrekens S, Roth SI, et al. (2010) Osteoblast precursors, but not mature osteoblasts, move into developing and fractured bones along with invading blood vessels. Dev Cell 19: 329-344.

43. Marsell R, Einhorn TA (2011) The biology of fracture healing. Injury 42: 551-555.

44. Kusumbe AP, Ramasamy SK, Adams RH (2014) Coupling of angiogenesis and osteogenesis by a specific vessel subtype in bone. Nature 507: 323-328.

45. Ramasamy SK, Kusumbe AP, Wang L, Adams RH (2014) Endothelial notch activity promotes angiogenesis and osteogenesis in bone. Nature 507: 376-380.

46. Maes C, Clemens TL (2014) Angiogenic-osteogenic coupling: the endothelial perspective. Bonekey Rep 3: 578.

47. Caliaperoumal G, Souyet $M$, Bensidhoum M, Petite H, Anagnostou $F$ (2018) Type 2 diabetes impairs angiogenesis and osteogenesis in calvarial defects: MicroCT study in ZDF rats. Bone 112: 161-172.

48. Cooper GM, Mooney MP, Gosain AK, Campbell PG, Losee JE (2010) Testing the critical size in calvarial bone defects: revisiting the concept of a critical-size defect. Plast Reconst Surg 125: 1685-1692.

49. Peng J, Hui K, Hao C, Peng Z, Gao QX, et al. (2016) Low bone turnover and reduced angiogenesis in streptozotocin-induced osteoporotic mice. Connect Tissue Res 57: 277-289.

50. Stabley JN, Prisby RD, Behnke BJ, Delp MD (2015) Type 2 diabetes alters bone and marrow blood flow and vascular control mechanisms in the ZDF rat. J Endocrinol 225: 47-58.

51. Neumann T, Lodes S, Kästner B, Lehmann T, Hans D, et al. (2016) Trabecular bone score in type 1 diabetes--a cross-sectional study. Osteoporos Int 27: 127-133.

52. Shah VN, Carpenter RD, Ferguson VL, Schwartz AV (2018) Bone health in type 1 diabetes. Curr Opin Endocrinol Diabetes Obes 25 231-236.
53. Oikawa A, Siragusa M, Quaini F, Mangialardi G, Katare RG, et al. (2010) Diabetes mellitus induces bone marrow microangiopathy. Arterioscler Thromb Vasc Biol 30: 498-508.

54. Peng J, Qu H, Peng J, Luo TY, Lv FJ, et al. (2016) Abnormal spontaneous brain activity in type 2 diabetes with and without microangiopathy revealed by regional homogeneity. Eur J Radiol 85: 607-615.

55. Zhang C, Wang KZ, Qiang H, Tang YL, Li Q, et al. (2010) Angiopoiesis and bone regeneration via co-expression of the hVEGF and hBMP genes from an adeno-associated viral vector in vitro and in vivo. Acta Pharmacol Sin 31: 821-830.

56. Zhang C, Ma J, Li M, Li XH, Dang XQ, et al. (2015) Repair effect of coexpression of the hVEGF and hBMP genes via an adeno-associated virus vector in a rabbit model of early steroid-induced avascular necrosis of the femoral head. Transl Res 166: 269-280.

57. Yamagishi S (2011) Role of advanced glycation end products (AGEs) in osteoporosis in diabetes. Curr Drug Targets 12: 2096-2102.

58. Graves DT, Kayal RA (2008) Diabetic complications and dysregulated innate immunity. Front Biosci 13: 1227-1239.

59. Nikolajczyk BS, Jagannathan-Bogdan M, Shin H, Gyurko R (2011) State of the union between metabolism and the immune system in type 2 diabetes. Genes Immun 12: 239-250.

60. Giacco F, Brownlee M (2010) Oxidative stress and diabetic complications. Circ Res 107: 1058-1070.

61. Pitocco D, Zaccardi F, Di Stasio E, Romitelli F, Santini SA, et al. (2010) Oxidative stress, nitric oxide, and diabetes. Rev Diabet Stud 7: 15-25.

62. Pitocco D, Tesauro M, Alessandro R, Ghirlanda G, Cardillo C (2013) Oxidative stress in diabetes: implications for vascular and other complications. Int J Mol Sci 14: 21525-21550.

63. Folli F, Corradi D, Fanti P, Davalli A, Paez A, et al. (2011) The role of oxidative stress in the pathogenesis of type 2 diabetes mellitus micro- and macrovascular complications: avenues for a mechanisticbased therapeutic approach. Curr Diabetes Rev 7: 313-324.

64. Lee NK, Choi YG, Baik JY, Han SY, Jeong DW, et al. (2005) A crucial role for reactive oxygen species in RANKL-induced osteoclast differentiation. Blood 106: 852-859.

65. Tanaka S, Nakamura K, Takahasi N, Suda T (2005) Role of RANKL in physiological and pathological bone resorption and therapeutics targeting the RANKL-RANK signaling system. Immunol Rev 208: 30-49.

66. Ha H, Kwak HB, Lee SW, Jin HM, Kim HM, et al. (2004) Reactive oxygen species mediate RANK signaling in osteoclasts. Exp Cell Res 301: 119-127.

67. Alikhani M, Alikhani Z, Boyd C, MacLellan CM, Raptis M, et al. (2007) Advanced glycation end products stimulate osteoblast apoptosis via the MAP kinase and cytosolic apoptotic pathways. Bone 40: 345353.

68. Cohen MM Jr (2013) Perspectives on RAGE signaling and its role in cardiovascular disease. Review Am J Med Genet A 161: 2750-2755.

69. Yao D, Brownlee M (2010) Hyperglycemia-induced reactive oxygen species increase expression of the receptor for advanced glycation end products (RAGE) and RAGE ligands. Diabetes 59: 249-255.

70. Mohazzab KM, Kaminski PM, Wolin MS (1994) NADH oxidoreductase is a major source of superoxide anion in bovine coronary artery endothelium. Am J Physiol 266: H2568-H2572.

71. Bartell SM, Kim HN, Ambrogini E, Han L, lyer S, et al. (2014) FoxO proteins restrain osteoclastogenesis and bone resorption by attenuating $\mathrm{H}_{2} \mathrm{O}_{2}$ accumulation. Nat Commun 5: 3773 . 
72. Wang $\mathrm{Y}$, Dong $\mathrm{G}$, Jeon $\mathrm{HH}$, Elazizi M, La LB, et al. (2015) FOXO1 mediates RANKL-induced osteoclast formation and activity. J Immunol 194: 2878-2887.

73. Kang J, de Brito Bezerra B, Pacios S, Andriankaja O, Li Y, et al. (2012) Aggregatibacter actinomycetem comitans infection enhances apoptosis in vivo through a caspase-3-dependent mechanism in experimental periodontitis. Infect Immun 80: 2247-2256.

74. Liu R, Bal HS, Desta T, Krothapalli N, Alyassi M, et al. (2006) Diabetes enhances periodontal bone loss through enhanced resorption and diminished bone formation. J Dent Res 85: 510-514.

75. Andriankaja OM, Galicia J, Dong G, Xiao W, Alawi F, et al. (2012) Gene expression dynamics during diabetic periodontitis. J Dent Res 91: 1160-1165.

76. Pacios S, Andriankaja O, Kang J, Alnammary M, Bae J, et al. (2013) Bacterial infection increases periodontal bone loss in diabetic rats through enhanced apoptosis. Am J Pathol 183: 1928-1935.

77. Alblowi J, Tian C, F Siqueira MF, Kayal R, McKenzie E, et al. (2013) Chemokine expression is upregulated in chondrocytes in diabetic fracture healing. Bone 53: 294-300.

78. Jiao H, Xiao E, Graves DT (2015) Diabetes and its effect on bone and fracture healing. Curr Osteoporos Rep 13: 327-335.

79. Alblowi J, Kayal RA, Siqueira M, McKenzie E, Krothapalli N, et al. (2009) High levels of tumor necrosis factor-alpha contribute to accelerated loss of cartilage in diabetic fracture healing. Am J Pathol 175: $1574-1585$

80. Engebretson SP, Hey-Hadavi J, Ehrhardt FJ, Hsu D, Celenti RS, et al. (2004) Gingival crevicular fluid levels of interleukin-1beta and glycemic control in patients with chronic periodontitis and type 2 diabetes. J Periodontol 75: 1203-1208.

81. Engebretson S, Chertog R, Nichols A, Hey-Hadavi J, Celenti R, et al. (2007) Plasma levels of tumour necrosis factor-alpha in patients with chronic periodontitis and type 2 diabetes. J Clin Periodontol 34: 18-24.

82. Kurtiş B, Tüter G, Serdar M, Akdemir P, Uygur C, et al. (2005) Gingival crevicular fluid levels of monocyte chemoattractant protein-1 and tumor necrosis factor-alpha in patients with chronic and aggressive periodontitis. J Periodontol 76: 1849-1855.

83. Salvi GE, Yalda B, Collins JG, Jones BH, Smith FW, et al. (1997) Inflammatory mediator response as a potential risk marker for periodontal diseases in insulin-dependent diabetes mellitus patients. J Periodontol 68: 127-135.

84. Salvi GE, Collins JG, Yalda B, Arnold RR, Lang NP, et al. (1997) Monocytic TNF alpha secretion patterns in IDDM patients with periodontal diseases. J Clin Periodontol 24: 8-16.

85. Richards D, Rutherford RB (1988) The effects of interleukin 1 on collagenolytic activity and prostaglandin-E secretion by human periodontal-ligament and gingival fibroblasts. Arch Oral Biol 33: 237-243.

86. Sarkar PD, Choudhury AB (2013) Relationships between serum osteocalcin levels versus blood glucose, insulin resistance and markers of systemic inflammation in central Indian type 2 diabetic patients. Eur Rev Med Pharmacol Sci 17: 1631-1635.

87. Silva JA, Lopes Ferrucci D, Peroni LA, de Paula Ishi E, Rossa-Junior C, et al. (2012) Periodontal disease-associated compensatory expression of osteoprotegerin is lost in type 1 diabetes mellitus and correlates with alveolar bone destruction by regulating osteoclastogenesis. Cells Tissues Organs 196: 137-150.
88. Silva JA, Ferrucci DL, Peroni LA, Abrahão PG, Salamene AF, et al. (2012) Sequential IL-23 and IL-17 and increased Mmp8 and Mmp14 expression characterize the progression of an experimental model of periodontal disease in type 1 diabetes. J Cell Physiol 227: 24412450.

89. Belibasakis GN, Bostanci N (2012) The RANKL-OPG system in clinical periodontology. J Clin Periodontol 39: 239-248.

90. Lu HK, Chen YL, Chang HC, Li CL, Kuo MY (2006) Identification of the osteoprotegerin/receptor activator of nuclear factor-kappa B ligand system in gingival crevicular fluid and tissue of patients with chronic periodontitis. J Periodontal Res 41: 354-360.

91. Mahamed DA, Marleau A, Alnaeeli M, Singh B, Zhang X, et al. (2005) G(-) anaerobes-reactive CD4+T-cells trigger RANKL-mediated enhanced alveolar bone loss in diabetic NOD mice. Diabetes 54: 1477-1486.

92. Katayama Y, Akatsu T, Yamamoto M, Kugai N, Nagata N (1996) Role of non-enzymatic glycosylation of type I collagen in diabetic osteopenia. J Bone Miner Res 11: 931-937.

93. Stolzing A, Sellers D, Llewelyn O, Scutt A (2010) Diabetes induced changes in rat mesenchymal stem cells. Cells Tissues Organs 191: 453-465.

94. García-Hernández A, Arzate H, Gil-Chavarría I, Rojo R, MorenoFierros L, et al. (2012) High glucose concentrations alter the biomineralization process in human osteoblastic cells. Bone 50 : 276-288.

95. Bastos AS, Graves DT, de Melo Loureiro AP, Rossa Júnior C, Abdalla DSP, et al. (2012) Lipid peroxidation is associated with the severity of periodontal disease and local inflammatory markers in patients with type 2 diabetes. J Clin Endocrinol Metab 97: E1353-E1362.

96. Santos VR, Lima JA, Gonçalves TE, Bastos MF, Figueiredo LC, et al. (2010) Receptor activator of nuclear factor-kappa B ligand/ osteoprotegerin ratio in sites of chronic periodontitis of subjects with poorly and well-controlled type 2 diabetes. J Periodontol 81: $1455-1465$

97. Drosatos-Tampakaki Z, Drosatos K, Siegelin Y, Gong S, Khan $S$, et al. (2014) Palmitic acid and DGAT1 deficiency enhance osteoclastogenesis, while oleic acid-induced triglyceride formation prevents it. J Bone Miner Res 29: 1183-1195.

98. Miranda TS, Feres M, Retamal-Valdés B, Perez-Chaparro PJ, Macie SS, et al. (2017) Influence of glycemic control on the levels of subgingival periodontal pathogens in patients with generalized chronic periodontitis and type 2 diabetes. J Appl Oral Sci 25: 82-89.

99. Valverde $\mathrm{P}, \mathrm{Tu} \mathrm{Q}$, Chen J (2005) BSP and RANKL induce osteoclastogenesis and bone resorption synergistically. J Bone Miner Res 20: 1669-1679.

100. Kozusko SD, Riccio C, Goulart M, Bumgardner J, Jing XL, et al. (2018) Chitosan as a bone scaffold biomaterial. J Craniofacial Surg 29: 17881793.

101. Kumbhar SG, Pawar SH (2017) Self-functionalized, oppositely charged chitosan-alginate scaffolds for biomedical applications. Biotechnol Ind J 13: 130

102. Rodríguez-Vázquez M, Vega-Ruiz B, Ramos-Zúñiga $R$, Saldaña-Koppel DA, Quiñones-Olvera LF (2015) Chitosan and its potential use as a scaffold for tissue engineering in regenerative medicine. Bio Med Res Int 2015: 821279.

103. Jiang T, Kumbar SG, Nair LS, Laurencin CT (2008) Biologically active chitosan systems for tissue engineering and regenerative medicine. Curr Top Med Chem 8: 354-364. 
104. Dhandayuthapani B, Yoshida Ya, Maekawa T, Kumar DS (2011) Polymeric scaffolds in tissue engineering application: a review. Int Polymer Sci 2011: 290602.

105. Hubbell JA (1999) Bioactive biomaterials. Curr Opin Biotechnol 10: 123-129.

106. Malafaya PB, Santos TC, van Griensven M, Reis RL (2008) Morphology, mechanical characterization and in vivo neo-vascularization of chitosan particle aggregated scaffolds architectures. Biomaterials 29: 3914-3926.

107. La WG, Jang J, Kim BS, Lee MS, Cho DW, et al. (2016) Systemically replicated organic and inorganic bony microenvironment for new bone formation generated by a 3D printing technology. RSC Adv 6: 11546-11553.

108. Khan F, Tare RS, Oreffo RO, Bradley M (2009) Versatile biocompatible polymer hydrogels: scaffolds for cell growth. Angew Chem Int Ed Engl 48: 978-982.

109. Ko HF, Sfeir C, Kumta PN (2010) Novel synthesis strategies for natural polymer and composite biomaterials as potential scaffolds for tissue engineering. Philos Trans A Math Phys Eng Sci 368: 1981-1997.

110. Vukajlovic D, Parker J, Bretcanu O, Novakovic K (2019) Chitosan based polymer/bioglass composites for tissue engineering applications. Mater Sci Eng C Mater Biol 96: 955-967.

111. Li Y, Kim JH, Choi EH, Han I (2019) Promotion of osteogenic differentiation by non-thermal biocompatible plasma treated chitosan scaffold. Sci Rep 9: 3712.

112. Costa-Pinto AR, Reis RL, Neves NM (2011) Scaffolds based bone tissue engineering: the role of chitosan. Tissue Eng Part B Rev 17 331-347.

113. Costa-Pinto AR, Correlo VM, Sol PC, Bhattacharya M, Charbord $P$, et al. (2009) Osteogenic differentiation of human bone marrow mesenchymal stem cells seeded on melt based chitosan scaffolds for bone tissue engineering applications. Biomacromolecules 10: 2067-2073.

114. Suh JK, Matthew HW (2000) Application of chitosan-based polysaccharide biomaterials in cartilage tissue engineering: a review. Biomaterials 24: 2589-2598.

115. Gandhi JK, Opara EC, Brey EM (2013) Alginate-based strategies for therapeutic vascularization. Ther Deliv 4: 327-341.

116. Neufurth $M$, Wang $X$, Schröder $H C$, Feng $Q$, Diehl-Seifert $B$, et al. (2014) Engineering a morphogenetically active hydrogel for bioprinting of bioartificial tissue derived from human osteoblast-like SaOS-2 cells. Biomaterials 35: 8810-8819.

117. Nakaoka R, Hirano Y, Mooney DJ, Tsuchiya T, Matsuoka A (2013) Study on the potential of RGD- and PHSRN-modified alginates as artificial extracellular matrices for engineering bone. J Artif Organs 16: $284-293$

118. Saltz A, Kandalam U (2016) Mesenchymal stem cells and alginate microcarriers for craniofacial bone tissue engineering: a review. J Biomed Mater Res A 104: 1276-1284.

119. Venkatesan J, Nithya R, Sudha PN, Kim SK (2014) Role of alginate in bone tissue engineering. Adv Food Nutr Res 73: 45-57.

120. Kong HJ, Smith MK, Mooney DJ (2003) Designing alginate hydrogels to maintain viability of immobilized cells. Biomaterials 24: 4023 4029.
121. Fan J, Park H, Lee MK, Bezouglaia O, Fartash A, et al. (2014) Adiposederived stem cells and BMP-2 delivery in chitosan-based 3D constructs to enhance bone regeneration in a rat mandibular defect model. Tissue Eng Part A 20: 2169-2179.

122. Agrali OB, Yildirim S, Ozener HO, Köse KN, Ozbeyli D, et al. (2018) Evaluation of the effectiveness of esterified hyaluronic acid fibers on bone regeneration in rat calvarial defects. BioMed Res Int 2018 3874131.

123. Pandit AH, Mazumdar N, Ahmad S (2019) Periodate oxidized hyaluronic acid-based hydrogel scaffolds for tissue engineering applications. Int J Biol Macromol 137: 853-869.

124. Solchaga LA, Gao J, Dennis JE, Awadallah A, Lundberg M, et al. (2002) Treatment of osteochondral defects with autologous bone marrow in a hyaluronan-based delivery vehicle. Tissue Eng 8: 333-347.

125. Chen S, Zhao XJ, Du C (2018) Macroporous poly (L-lactic acid)/ chitosan nanofibrous scaffolds through cloud point thermally induced phase separation for enhanced bone regeneration. Eur Polym J 109: 303-316.

126. Munhoz MAS, Hirata HH, Plepis AMG, Martins VCA, Cunha MR (2018) Use of collagen/chitosan sponges mineralized with hydroxyapatite for the repair of cranial defects in rats. Injury 49: 2154-2160.

127. Carletti E, Motta A, Migliaresi C (2011) Scaffolds for tissue engineering and 3D cell culture. Methods Mol Biol 695: 17-39.

128. Jiang T, Khan Y, Nair LS, Abdel-Fattah WI, Laurencin CT (2010) Functionalization of chitosan/poly (lactic acid-glycolic acid) sintered microsphere scaffolds via surface heparinization for bone tissue engineering. J Biomed Mater Res A 93: 1193-1208.

129. Ouasti S, Donno R, Cellesi F, Sherratt MJ, Terenghi G, et al. (2011) Network connectivity, mechanical properties and cell adhesion for hyaluronic acid/PEG hydrogels. Biomaterials 32: 6456-6470.

130. Moshaverinia A, Chen C, Xu X, Akiyama K, Ansari S, et al. (2014) Bone regeneration potential of stem cells derived from periodontal ligament or gingival tissue sources encapsulated in RGD-modified alginate scaffold. Tissue Eng Part A 20: 611-621.

131. Rocha LB, Goissis G, Rossi MA (2002) Biocompatibility of anionic collagen matrix as scaffold for bone healing. Biomaterials 23: 449456.

132. Nejadnik MR, Yang $X$, Bongio $M$, Alghamdi HS, van den Beucken JJ, et al. (2014) Self-healing hybrid nanocomposites consisting of bisphosphonated hyaluronan and calcium phosphate nanoparticles. Biomaterials 35: 6918-6929.

133. Müller WE, Schröder HC, Feng $Q$, Schlossmacher $U$, Link $T$, et al. (2015) Development of a morphogenetically active scaffold for three-dimensional growth of bone cells: biosilica-alginate hydrogel for SaOS-2 cell cultivation. J Tissue Eng Regen Med 9: E39-E50.

134. Coimbra P, Ferreira $P$, de Sousa HC, Batista $P$, Rodrigues MA, et al. (2011) Preparation and chemical and biological characterization of a pectin/chitosan polyelectrolyte complex scaffold for possible bone tissue engineering applications. Int J Biol Macromol 48: 112-118.

135. Sukpaita T, Chirachanchai S, Suwattanachai P, Everts V, Pimkhaokham A, et al. (2019) In vivo bone regeneration induced by a scaffold of chitosan/dicarboxylic acid seeded with human periodontal ligament cells. Int J Mol Sci 20: 4883.

136. Liu LS, Thompson AY, Heidaran MA, Poser JW, Spiro RC (1999) An osteoconductive collagen/hyaluronate matrix for bone regeneration. Biomaterials 20: 1097-1108. 
137. Hile DD, Sonis ST, Doherty SA, Tian X, Zhang Q, et al. (2005) Dimensional stability of the alveolar ridge after implantation of a bioabsorbable bone graft substitute: a radiographic and histomorphometric study in rats. J Oral Implantol 31: 68-76.

138. Chatzipetros E, Christopoulos P, Donta C, Tosios KI, Tsiambas E, et al. (2018) Research application of nano-hydroxyapatite/chitosan scaffolds on rat calvarial critical-sized defects: a pilot study. Med Oral Patol Oral Cir Bucal 23: e625-e632.

139. Hu JX, Ran JB, Chen S, Jiang P, Shen XY, et al. (2016) Carboxylated agarose (CA)-silk fibroin (SF) dual confluent matrices containing oriented hydroxyapatite (HA) crystals: biomimetic organic/inorganic composites for tibia repair. Biomacromolecules 17: 2437-2447.

140. Luo Y, Lode A, Wu C, Chang J, Gelinsky M (2015) Alginate/ nanohydroxyapatite scaffolds with designed core/shell structures fabricated by 3D plotting and in situ mineralization for bone tissue engineering. ACS Appl Mater Interfaces 7: 6541-6549.

141. Bhattacharyya S, Guillot S, Dabboue H, Tranchant JF, Salvetat JP (2008) Carbon nanotubes as structural nanofibers for hyaluronic acid hydrogel scaffolds. Biomacromolecules 9: 505-509.

142. Zhao L, Li J, Zhang L, Wanga Y, Wang J, et al. (2016) Preparation and characterization of calcium phosphate/pectin scaffolds for bone tissue engineering. RSC Adv 6: 62071-62082.

143. Shi H, Ye X, He F, Ye J (2019) Improving osteogenesis of calcium phosphate bone cement by incorporating with lysine: an in vitro study. Colloids Surf B Biointerfaces 177: 462-469.

144. Ivan FD, Marian A, Tanase CE, Butnaru M, Verestiuc L (2013) Biomimetic composites based on calcium phosphates and chitosanhyaluronic acid with potential application in bone tissue engineering. Key Eng Mater 587: 191-196.

145. Miljkovic ND, Cooper GM, Hott SL, Disalle BF, Gawalt ES, et al. (2009) Calcium aluminate, RGD-modified calcium aluminate, and betatricalcium phosphate implants in a calvarial defect. J Craniofac Surg 20: 1538-1543.

146. Hu H, Zhao P, Liu J, Ke Q, Zhang C, et al. (2018) Lanthanum phosphate/ chitosan scaffolds enhance cytocompatibility and osteogenic efficiency via the Wnt/ $\beta$-catenin pathway. J Nanobiotechnol 16: 98.

147. Safiaghdam H, Nokhbatolfoghahaei H, Khojasteh A (2019) Therapeutic metallic ions in bone tissue engineering: A systematic review of the literature. Iran J Pharm Res 18: 101-118.

148. D'Mello S, Elangovan S, Hong L, Ross RD, Sumner DR, et al. (2015) Incorporation of copper into chitosan scaffolds promotes bone regeneration in rat calvarial defects. J Biomed Mater Res Part B-Appl Biomaterials 103: 1044-1049.

149. Cai K, Hu Y, Jandt KD, Wang Y (2008) Surface modification of titanium thin film with chitosan via electrostatic self-assembly technique and its influence on osteoblast growth behavior. J Mater Sci Mater Med 19: 499-506.

150. Bumgardner JD, Chesnutt BM, Yuan Y, Yang Y, Appleford M, et al. (2007) The integration of chitosan-coated titanium in bone: an in vivo study in rabbits. Implant Dent 16: 66-79.

151. Koshihara Y, Kawamura M, Oda H, Higaki S (1987) In vitro calcification in human osteoblastic cell line derived from periosteum. Biochem Biophys Res Commun 145: 651-657.

152. Keselowsky BG, Collard DM, García AJ (2005) Integrin binding specificity regulates biomaterial surface chemistry effects on cell differentiation. Proc Natl Acad Sci U S A 102: 5953-5957.
153. Chang HI, Wang Y (2011) Cell responses to surface and architecture of tissue engineering scaffolds. In: Daniel Eberli (eds) Regenerative Medicine and Tissue Engineering-Cells and Biomaterials. IntechOpen 569-588.

154. Chung TW, Liu DZ, Wang SY, Wang SS (2003) Enhancement of the growth of human endothelial cells by surface roughness at nanometer scale. Biomaterials 24: 4655-4661.

155. Moshaverinia A, Ansari S, Chen C, Xu X, Akiyama K, et al. (2013) Coencapsulation of anti-BMP2 monoclonal antibody and mesenchymal stem cells in alginate microspheres for bone tissue engineering. Biomaterials 34: 6572-6579.

156. Hulsart-Billström G, Yuen PK, Marsell R, Hilborn J, Larsson S, et al. (2013) Bisphosphonate-linked hyaluronic acid hydrogel sequesters and enzymatically releases active bone morphogenetic protein-2 for induction of osteogenic differentiation. Biomacromolecules 14 : 3055-3063.

157. Kain MS, Einhorn TA (2005) Recombinant human bone morphogenetic proteins in the treatment of fractures. Foot Ankle Clin 10: 639-650.

158. Szpalski M, Gunzburg R (2005) Recombinant human bone morphogenetic protein-2: A novel osteoinductive alternative to autogenous bone graft? Acta Orthop Belg 71: 133-148.

159. Olthof MGL, Kempen DHR, Herrick JL, Yaszemski MJ, Dhert WJA, et al. (2018) Effect of different sustained bone morphogenetic protein-2 release kinetics on bone formation in poly(propylene fumarate) scaffolds. Biomed Mater Res B Appl Biomater 106: 477487.

160. Agrawal V, Sinha M (2017) A review on carrier systems for bone morphogenetic protein-2. J Biomed Mater Res B Appl Biomater 105: 904-925.

161. Romagnoli C, D’Asta F, Brandi ML (2013) Drug delivery using composite scaffolds in the context of bone tissue engineering. Clin Cases Miner Bone Metab 10: 155-161.

162. Kirker-Head CA, Boudrieau RJ, Kraus KH (2007) Use of bone morphogenetic proteins for augmentation of bone regeneration. J Am Vet Med Assoc 231: 1039-1055.

163. De Biase P, Capanna R (2005) Clinical applications of BMPs. Injury 36: S43-S46.

164. Giannoudis PV, Tzioupis C (2005) Clinical applications of BMP-7: The UK perspective. Injury 36: S47-S50.

165. Gautschi OP, Frey SP, Zellweger R (2007) Bone morphogenetic proteins in clinical applications. ANZ J Surg 77: 626-631.

166. Pi CJ, Liang KL, Ke ZY, Chen F, Cheng $Y$, et al. (2016) Adenovirusmediated expression of vascular endothelial growth factor-a potentiates bone morphogenetic protein9-induced osteogenic differentiation and bone formation. Biol Chem 397: 765-775.

167. Chen D, Zhao M, Mundy GR (2004) Bone Morphogenetic Proteins. Growth Factors 22: 233-241.

168. Lee SH, Shin $H$ (2007) Matrices and scaffolds for delivery of bioactive molecules in bone and cartilage tissue engineering. Adv Drug Deliv Rev 59: 339-359.

169. Kretlow JD, Klouda L, Mikos AG (2007) Injectable matrices and scaffolds for drug delivery in tissue engineering. Adv Drug Deliv Rev 59: 263-273. 
170. Ripamonti U, Klar RM, Renton L, Ferretti C (2010) Synergistic induction of bone formation by hOP- 1, TGF- $\beta 3$ and inhibition by zoledronate in macroporous coral-derived hydroxyapatites. Biomaterials 31: 6400-6410.

171. Ripamonti U, Parak R, Klar RM, Dickens C, Dix-Peek T, et al. (2016) The synergistic induction of bone formation by the osteogenic proteins of the TGF- $\beta$ supergene family. Biomaterials 104: 279-296.

172. Chapanian R, Amsden BG (2010) Combined and sequential delivery of bioactive $\operatorname{VEGF}(165)$ and HGF from poly(trimethylene carbonate) based photo-cross-linked elastomers. J Control Release 143: 53-63.

173. Copland IB, Garcia MA, Waller EK, Roback JD, Galipeau J (2013) The effect of platelet lysate fibrinogen on the functionality of MSCs in immunotherapy. Biomaterials 34: 7840-7850.

174. Meng Y, Huang X, Wu M, Yang X, Liu Y (2020) The Effect of autologous platelet concentrates on maxillary sinus augmentation: a metaanalysis of randomized controlled trials and systematic review. Biomed Res Int.

175. Wang X, Zhang Y, Choukroun J, Ghanaati S, Miron RJ (2018) Effects of an injectable platelet-rich fibrin on osteoblast behavior and bone tissue formation in comparison to platelet-rich plasma. Platelets 29: 48-55.

176. Kanno T, Takahashi T, Tsujisawa T, Ariyoshi W, Nishihara T (2005) Platelet-rich plasma enhances human osteoblast-like cell proliferation and differentiation. J Oral MaxillofacSurg 63: 362-369.

177. Raftery RM, Mencía-Castaño I, Sperger S, Chen G, Cavanagh B, et al. (2018) Delivery of the improved BMP-2-advanced plasmid DNA within a gene-activated scaffold accelerates mesenchymal stem cell osteogenesis and critical size defect repair. J Control Release 283 20-31.

178. Carmeliet P (2003) Angiogenesis in health and disease. Nat Med 9 : 653-660.

179. Risau W (1997) Mechanisms of angiogenesis. Nature 386: 671-674.

180. Chen RR, Silva EA, Yuen WW, Brock AA, Fischbach C, et al. (2007) Integrated approach to designing growth factor delivery systems. FASEB J 21: 3896-3903.

181. Lee K, Silva EA, Mooney DJ (2010) Growth factor delivery-based tissue engineering: general approaches and a review of recent developments. J Royal Soc Interfac 8: 153-170.

182. Yilgor P, Tuzlakoglu K, Reis RL, Hasirci N, Hasirci V (2009) Incorporation of a sequential BMP-2/BMP-7 delivery system into chitosan-based scaffolds for bone tissue engineering. Biomaterials 30: 3551-3559.

183. Yilgor P, Hasirci N, Hasirci V (2010) Sequential BMP-2/BMP-7 delivery from polyester nanocapsules. J Biomed Mater Res A 93: 528-536.

184. Simmons CA, Alsberg E, Hsiong S, Kim WJ, Mooney DJ (2004) Dual growth factor delivery and controlled scaffold degradation enhance in vivo bone formation by transplanted bone marrow stromal cells. Bone 35: 562-569.

185. Raiche AT, Puleo DA (2004) In vitro effects of combined and sequential delivery of two bone growth factors. Biomaterials 25 : 677-685.

186. Young S, Patel ZS, Kretlow JD, Murphy MB, Mountziaris PM, et al. (2009) Dose effect of dual delivery of vascular endothelial growth factor and bone morphogenetic protein-2 on bone regeneration in a rat critical-size defect model. Tissue Eng Part A 15: 2347-2362.

187. Kempen DH, Lu L, Heijink A, Hefferan TE, Creemers LB, et al. (2009) Effect of local sequential VEGF and BMP-2 delivery on ectopic and orthotopic bone regeneration. Biomaterials 30: 2816-2825.
188. Luo T, Zhang W, Shi B, Cheng X, Zhang Y (2012) Enhanced bone regeneration around dental implant with bone morphogenetic protein 2 gene and vascular endothelial growth factor protein delivery. Clin Oral Implants Res 23: 467-473.

189. Li B, Wang H, Qiu G, Su X, Wu Z (2016) Synergistic effects of vascular endothelial growth factor on bone morphogenetic proteins induced bone formation in vivo: influencing factors and future research directions. Biomed Res Int.

190. Cui Q, Dighe AS, Irvine JNJ (2013) Combined angiogenic and osteogenic factor delivery for bone regenerative engineering. Curr Pharm Des 19: 3374-3383.

191. Patel ZS, Young S, Tabata Y, Jansen JA, Wong ME, et al. (2008) Dual delivery of an angiogenic and an osteogenic growth factor for bone regeneration in a critical size defect model. Bone 43: 931-940.

192. Freeman I, Kedem A, Cohen S (2008) The effect of sulfation of alginate hydrogels on the specific binding and controlled release of heparin-binding proteins. Biomaterials 29: 3260-3268.

193. Freeman I, Cohen S (2009) The influence of the sequential delivery of angiogenic factors from affinity-binding alginate scaffolds on vascularization. Biomaterials 30: 2122-2131.

194. Perets A, Baruch Y, Weisbuch F, Shoshany G, Neufeld G, et al. (2002) Enhancing the vascularization of three-dimensional porous alginate scaffolds by incorporating controlled release basic fibroblast growth factor microspheres. J Biomed Mater Res A 65: 489-497.

195. Charoenlarp P, Rajendran AK, Iseki S (2017) Role of fibroblast growth factors in bone regeneration. Inflamm Regener 37: 10.

196. Murphy CM, O'Brien FJ, Little DG, Schindeler A (2013) Cell-scaffold interactions in the bone tissue engineering triad. Eur Cells Mater 26: $120-132$.

197. Deepa R, Paul W, Anilkumar TV, Sharma CP (2013) Differential healing of full thickness rabbit skin wound by fibroblast loaded chitosan sponge. J Biomater Tiss Eng 3: 261-272.

198. Sun HF, Wang XG, Hu XL, Yu WJ, You CG, et al. (2012) Promotion of angiogenesis by sustained release of rhGM-CSF from heparinized collagen/chitosan scaffolds. J Biomed Mater Res Part B 100B: 788798.

199. Thomas AM, Gomez AJ, Palma JL, Yap WT, Shea LD (2014) Heparinchitosan nanoparticle functionalization of porous poly(ethylene glycol) hydrogels for localized lentivirus delivery of angiogenic factors. Biomaterials 35: 8687-8693.

200. Amaral IF, Neiva I, da Silva FF, Sousa SR, Piloto AM, et al. (2013) Endothelialization of chitosan porous conduits via immobilization of a recombinant fibronectin fragment (rhFNIII(7-10)). Acta Biomaterialia 9: 5643-5652.

201. Bolshakov IN, Shestakova LA, Kotikov AR, Kaptyuk GI (2013) Experimental atherogenic inflammation of the great arteries in rabbits. Minimally invasive technology of morphological reconstruction of the vascular wall in the early stages of atherogenesis. J Basic Research 8: 343-350.

202. Bolshakov IN, Shestakova LA, Kotikov AR, Kaptyuk GI (2013) Experimental atherogenesis in rats. Morphological reconstruction of the wall of the main artery with polysaccharide biopolymers. J Basic Res 10: 557-563.

203. Kirichenko AK, Patlataya NN, Sharkova AF, Pevnev AA, Kontorev KV, et al. (2017) Pathomorphism of limb major vessels in experimental atherogenic inflammation. The role of adventitial intimal relations (review). CTM 9: 162-173. 
204. Pagano PJ, Gutterman DD (2007) The adventitia: the outs and ins of vascular disease. Cardiovasc Res 75: 636-639.

205. Ding X, Gao J, Wang Z, Awada H, Wang Y (2016) A shear-thinning hydrogel that extends in vivo bioactivity of FGF2. Biomaterials 111: 80-89.

206. Shahzadi L, Yar M, Jamal A, Siddiqi SA, Chaudhry AA, et al. (2016) Triethyl orthoformate covalently cross-linked chitosan-(poly vinyl) alcohol based biodegradable scaffolds with heparin-binding ability for promoting neovascularization. J Biomater Appl 31: 582-593.

207. Yar M, Gigliobianco G, Shahzadi L, Dew L, Siddiqi SA, et al. (2016) Production of chitosan PVA PCL hydrogels to bind heparin and induce angiogenesis. Int J Polymer Mater Polymer Biomater 65: 466-476.

208. Huang YC, Yang YT (2016) Effect of basic fibroblast growth factor released from chitosan-fucoidan nanoparticles on neurite extension. J Tissue Eng Regen Med 10: 418-427.

209. Zhang J, Li GP, Gao S, Yao Y, Pang LY, et al. (2014) Monocyte chemoattractant protein-1 released from polycaprolactone/ chitosan hybrid membrane to promote angiogenesis in vivo. J Bioact Compat Polym 29: 572-588.

210. Chen CK, Chang NJ, Wu YT, Fu E, Shen EC, et al. (2018) Bone formation using cross-linked chitosan scaffolds in rat calvarial defects. Implant Dent 27: 15-21.

211. Chang JF, Feng YF, Peng YS, Hsu SP, Pai MF, et al. (2014) Combined alkaline phosphatase and phosphorus levels as a predictor of mortality in maintenance hemodialysis patients. Medicine (Baltimore) 93: e106.

212. Yousaf MN (2009) Model substrates for studies of cell mobility. Curr Opin Chem Biol 13: 697-704.
213. Li H, Ji Q, Chen X, Sun Y, Xu Q, (2017) Accelerated bony defect healing based on chitosan thermosensitive hydrogel scaffolds embedded with chitosan nanoparticles for the delivery of BMP2 plasmid DNA. J Biomed Mater Res A 105: 265-273.

214. Bhattarai G, Lee YH, Lee MH, Park IS, Yi HK (2015) Insulin-like growth factor binding protein-3 affects osteogenic efficacy on dental implants in rat mandible. Mater Sci Eng C Mater Biol Appl 55: 490496.

215. Lee YH, Kim JS, Kim JE, Lee MH, Jeon JG, et al. (2017) Nanoparticle mediated PPAR $y$ gene delivery on dental implants improves osseointegration via mitochondrial biogenesis in diabetes mellitus rat model. Nanomedicine 13: 1821-1832.

216. Bhattarai G, Lee $\mathrm{YH}$, Lee $\mathrm{NH}$, Park IS, Lee MH, et al. (2013) PPARy delivered by Ch-GNPs onto titanium surfaces inhibits implantinduced inflammation and induces bone mineralization of MC3T3E1 osteoblast-like cells. Clin Oral Implants Res 24: 1101-1109.

217. Shue L, Yufeng Z, Mony U (2012) Biomaterials for periodontal regeneration: a review of ceramics and polymers. Biomatter 2: 271277.

218. Lauritano D, Limongelli L, Moreo G, Favia G, Carinci F (2020) Nanomaterials for periodontal tissue engineering: chitosan-based scaffolds. A systematic review. Nanomaterials (Basel) 10: 605.

219. Iviglia G, Kargozar S, Baino F (2019) Biomaterials, current strategies, and novel nano-technological approaches for periodontal regeneration. J Funct Biomater 10: 3.

220. Patlataja NN (2012) Replacement of bone tissue defects in the maxillofacial region using bone-plasticmaterial "BOL-HITAL". Dissertation for an academic degree Candidate of Medical Sciences. Krasnojarsk. 